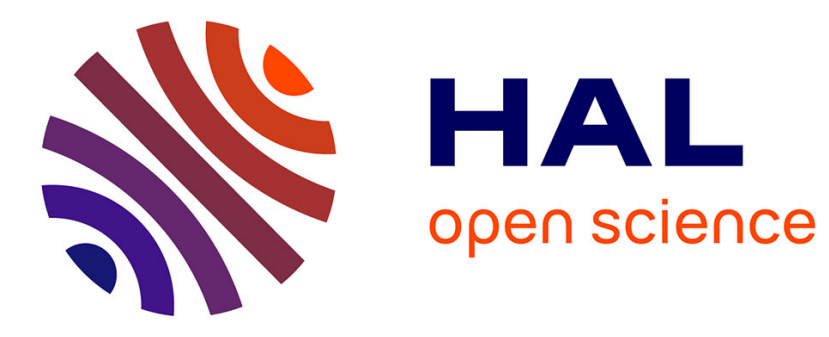

\title{
Coastal Fish Farms Are Settlement Sites for Juvenile Fish
}

Damian Fernandez-Jover, Pablo Sanchez-Jerez, Just Bayle-Sempere, Pablo Arechavala-Lopez, Laura Martinez-Rubio, Jose Angel Lopez Jimenez, Francisco Javier Martinez Lopez

\section{To cite this version:}

Damian Fernandez-Jover, Pablo Sanchez-Jerez, Just Bayle-Sempere, Pablo Arechavala-Lopez, Laura Martinez-Rubio, et al.. Coastal Fish Farms Are Settlement Sites for Juvenile Fish. Marine Environmental Research, 2009, 68 (2), pp.89. 10.1016/j.marenvres.2009.04.006 . hal-00491629

\section{HAL Id: hal-00491629 \\ https://hal.science/hal-00491629}

Submitted on 14 Jun 2010

HAL is a multi-disciplinary open access archive for the deposit and dissemination of scientific research documents, whether they are published or not. The documents may come from teaching and research institutions in France or abroad, or from public or private research centers.
L'archive ouverte pluridisciplinaire HAL, est destinée au dépôt et à la diffusion de documents scientifiques de niveau recherche, publiés ou non, émanant des établissements d'enseignement et de recherche français ou étrangers, des laboratoires publics ou privés. 


\section{Accepted Manuscript}

Coastal Fish Farms Are Settlement Sites for Juvenile Fish

Damian Fernandez-Jover, Pablo Sanchez-Jerez, Just Bayle-Sempere, Pablo

Arechavala-Lopez, Laura Martinez-Rubio, Jose Angel Lopez Jimenez,

Francisco Javier Martinez Lopez

PII:

S0141-1136(09)00041-5

DOI:

10.1016/j.marenvres.2009.04.006

Reference:

MERE 3334

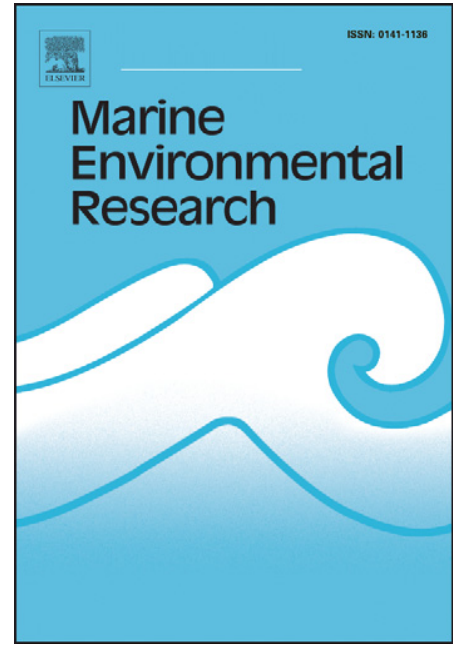

To appear in:

Marine Environmental Research

Received Date:

23 February 2009

Revised Date:

6 April 2009

Accepted Date:

14 April 2009

Please cite this article as: Fernandez-Jover, D., Sanchez-Jerez, P., Bayle-Sempere, J., Arechavala-Lopez, P., Martinez-Rubio, L., Jimenez, J.A.L., Lopez, F.J.M., Coastal Fish Farms Are Settlement Sites for Juvenile Fish, Marine Environmental Research (2009), doi: 10.1016/j.marenvres.2009.04.006

This is a PDF file of an unedited manuscript that has been accepted for publication. As a service to our customers we are providing this early version of the manuscript. The manuscript will undergo copyediting, typesetting, and review of the resulting proof before it is published in its final form. Please note that during the production process errors may be discovered which could affect the content, and all legal disclaimers that apply to the journal pertain. 


\title{
Coastal Fish Farms Are Settlement Sites for Juvenile Fish
}

Authors: Damian Fernandez-Jover ${ }^{\text {a,b, }}$, Pablo Sanchez-Jerez ${ }^{a}$, Just Bayle-Sempere ${ }^{a}$, Pablo Arechavala-Lopez ${ }^{\mathrm{a}}$, Laura Martinez-Rubio ${ }^{\mathrm{c}}$, Jose Angel Lopez Jimenez ${ }^{\mathrm{c}}$, Francisco Javier Martinez Lopez ${ }^{\mathrm{c}}$.

${ }^{\mathrm{a}}$ Dpt. Marine Sciences and Applied Biology. University of Alicante, P.O. Box. 99, E03080 Alicante, Spain

${ }^{\mathrm{b}}$ School of Marine and Tropical Biology, James Cook University, Queensland 4811, Australia

${ }^{c}$ Dpt. Physiology, Faculty of Biology, University of Murcia, Campus of Espinardo, P.O. Box 30100, Murcia, Spain

* Corresponding author. Tel +34 965903400. e-mail address jover@ua.es

\begin{abstract}
Two south-west Mediterranean fish farms were monitored over a period of 22 months to test if sea-cage fish farms act as settlement habitats for juvenile fish. Twenty juvenile fish species were found to settle at farms throughout the year. Fish assemblage composition varied markedly over time and was dependent on the spawning period for each species. The most abundant species were Oblada melanura, Atherina spp., Diplodus sargus, Boops boops and Liza aurata. Up to $3783 \pm 1730$ individuals/cage were found closely associated with the cages. Highest densities were observed during the warmer summer and autumn months. Zooplankton sampling and stomach content analyses of the most abundant species were done to assess prey availability, selectivity and diet overlap among species. Copepods were the main prey item for all juvenile fish species, irrespective of fish size. Ivlev's Index indicated that food was not a limiting factor for juvenile fish at farms. Furthermore, food pellets from the farm affected the food chain by modifying the fatty acid profiles of farm-associated zooplankton and juveniles of L. aurata and O. melanura. These results show that aquaculture can directly influence the body composition of juvenile fish that recruit to sea-cage fish farms.
\end{abstract}


Keywords: Juvenile fish, fatty acid, biomarker, zooplankton, stomach content, diet, aquaculture impact.

\section{INTRODUCTION}

Settlement and recruitment of fish to nursery habitats may be determined by a combination of several factors, such as spawning strategies of breeding stocks (Sherman et al. 1984), chemical cues (Sweatman, 1988), or oceanographic features (Govoni and Pietrafesa, 1994), amongst others. Despite considerable research, factors leading to habitat choice by pre-settlement fish remain unclear. Fish recruit to a wide variety of natural environments, but also to artificial structures like docks, oil jetties (Rilov and Benayahu, 2000), oil platforms (Love et al., 1994), fish attraction devices (FADs; Gooding and Magnuson, 1967), artificial reefs (Beets, 1989), and bivalve aquaculture rafts (Powers et al., 2007). In the case of FADs, the two most widely accepted explanations for this behaviour are the 'meeting-point theory' - where fish aggregate around a reference site in order to form schools and therefore gain protection; and the 'indicator-log theory' - where fish aggregate around drifting objects which accumulate in frontal zones where food may be more abundant (Freon and Dagorn, 2000). Factors which induce an individual to choose an artificial structure instead of a natural environment remain unclear, though this behaviour may have important consequences for population dynamics due to potentially differential predation rates or food availability between natural and artificial sites.

As sea-cage aquaculture production in the Mediterranean has continued to increase in recent years (e.g. $>160,000 \mathrm{t} \mathrm{y}^{-1}$ of sea-bream and sea-bass; FAO, 2007), so too have concerns regarding the potential impacts of aquaculture on the natural environment of the surrounding area. Impacts on wild fish populations have attracted considerable attention due to environmental and economical interests. Sea-cage aquaculture has a strong aggregative effect on wild fish (Dempster et al., 2002). Attracted fish actively feed on uneaten food pellets which fall through nets (Fernandez-Jover et al., 2008), while carnivorous species are attracted by the increased abundance of prey (SanchezJerez et al. 2008). Wild fish, which take advantage of the ready and constant availability of artificial food resources around fish farms, may also experience a change in their fatty acid (FA) composition with unknown consequences for their physiology. 
To date, there is an almost total lack of knowledge regarding the role of fish farms as settlement habitats for juvenile fish. Therefore, to determine whether sea-cages are used by coastal fishes as settlement habitat, fish censuses and captures were carried out monthly over a 2-year period at two sea-bass and sea-bream farms in the south-western (SW) Mediterranean Sea. Stomach content analysis of captured individuals representing the dominant settling species were also carried out. Zooplankton tows immediately adjacent to the sea-cages were made in order to investigate changes in food utilization, food availability and prey selectivity by juvenile fish. Analysis of the FA composition of food pellets, zooplankton and juvenile fish were also made to test the hypothesis that lipids contained in food pellets influenced the food chain and led to changes in the physiology of settling juvenile fish around sea-cages.

\section{MATERIALS AND METHODS}

\subsection{Study Sites}

Two Mediterranean fish farms, separated by $45 \mathrm{~km}$, were chosen off south-eastern Spain at Campello (38 25'12.58"N; 0 20'48.88"W) and Guardamar (38 5'45.88"N; $\left.0^{\circ} 36^{\prime} 15.84^{\prime \prime} \mathrm{W}\right)$. The farm at Campello was located $3.2 \mathrm{~km}$ offshore in an average depth of $28.6 \mathrm{~m}$. The farm consisted of 12 circular cages each having a diameter of $19 \mathrm{~m}$ and a height of $17 \mathrm{~m}$, and producing $300 \mathrm{t} \mathrm{yr}^{-1}$ of fish. The farm at Guardamar was located 3.7 $\mathrm{km}$ offshore and sited in a depth of $24 \mathrm{~m}$, and consisted of 24 circular cages, each having a diameter of $19 \mathrm{~m}$ and a height of $15 \mathrm{~m}$, and producing $1100 \mathrm{t} \mathrm{yr}-1$ of fish. Both farms reared sea-bass (Dicentrarchus labrax) and sea-bream (Sparus aurata).

\subsection{Spatial and Temporal Variability in Aggregated Species}

The composition and abundance of juvenile fishes ( $<40 \mathrm{~mm}$ standard length- SL) around floating cages was estimated monthly from April 2006 to January 2008. A pilot study showed that juveniles aggregated around $(<2-3 \mathrm{~m})$ the floating cage tubes and in the first $3 \mathrm{~m}$ of the water column. Sampling was therefore restricted to this area. Sampling was carried out on three randomly selected days each month. On each sampling occasion, one diver slowly swam around each of three randomly selected 
cages to census the composition, abundance, and estimates of the size classes of juvenile fishes. Spaces between cage structures were carefully searched for hiding individuals. A second diver then captured several schools of fish using a dipnet, separating each school sampled into separate bags based on species and size. Fish were sampled between 0900 and 1100 on each day of sampling.

\subsection{Diet}

Captured juveniles were stored in 70\% ethanol. Once in the laboratory, they were identified (to species where possible) and standard length (SL) measured with a calliper to the nearest $0.1 \mathrm{~mm}$. Stomachs were then removed, and all contents identified to the lowest taxonomic level possible and counted. Only entire organisms and detached heads were identified and counted. Some stomachs contained large numbers of copepod eggs, which were not used in calculation of the relative frequency of prey items. Overall, the stomachs of 82 Atherina spp., 54 Boops boops, 48 Diplodus sargus, 68 Liza aurata and 67 Oblada melanura were analyzed.

\subsection{Prey Selectivity}

To estimate food availability, zooplankton samples were collected using vertical tows (17 $\mathrm{m}$ - surface). Two tows were made on each sampling day using a $60 \mathrm{~cm}$ diameter plankton net having a $200 \mu \mathrm{m}$ mesh size. Ivlev's index ( $E$; Ivlev, 1961) was used to estimate prey selectivity using the formula: $E=\left(r_{i}-p_{i}\right) /\left(r_{i}+p_{i}\right)$, where $r_{i}$ is the relative abundance of the food category $i$ in the stomach (as a proportion of all stomach contents) and $p_{i}$ is the availability of this prey in the environment. Values range from - 1 (total rejection or inaccessibility of the prey) to +1 (active selection of the prey), and zero indicates random feeding. Cage attached organisms (such as amphipods) were not used for calculations since it was virtually impossible to estimate their abundances from plankton tows. Prey that were absent from stomach contents were not included in calculations since their inclusion would have influenced the results for all other prey items (Johnson, 1980).

\subsection{Fatty Acid Composition}


The FA profile of Liza aurata (12 individuals, 18-28 $\mathrm{mm}$ standard length - SL) and Oblada melanura (8 individuals, 15-20 mm SL), also collected with a dipnet, from around farms was compared to control populations captured at least $10 \mathrm{~km}$ away from the nearest fish farm. L. aurata were captured in September and October 2007, while $O$. melanura were captured in June and July 2007. Individuals captured at the two farms were pooled using the same number of fish from each location. Those captured at the two control locations were also pooled in this way. The FA composition of zooplankton was also analyzed. At each location, two zooplankton tows were made near farms and compared with tows made $\geq 3 \mathrm{~km}$ away from farms. Tows were done with the same methodology applied to the prey selectivity study. Once in the laboratory, samples were filtered and frozen at $-18^{\circ} \mathrm{C}$.

After whole individual fish tissue was filter homogenised, the FA composition of the total lipid fraction was determined by fat extraction following the method of Folch et al. (1957), using a mixture of chloroform and methanol (1:1 for the first extraction and 2:1 for the second). Fatty acid methyl ester (FAME) samples were analyzed according to the method of Stoffel et al. (1959) by gas-liquid chromatography using a SP${ }^{\mathrm{TM}} 2560$ flexible fused silica capillary column (100 m length, $0.25 \mathrm{~mm}$ internal diameter and $0.20 \mu \mathrm{m}$ film thickness; SUPELCO) in a Hewlett-Packard 5890 gas chromatograph. Peaks were identified by comparison of their retention times with appropriate FAME standards purchased from Sigma Chemical Company (St. Louis, MO, USA). Individual FA concentrations were expressed as percentages of the total content.

Budge et al. (2001) detected inputs of terrestrial organic matter in the marine environment using the $\sum(18: 2 \omega 6,18: 3 \omega 3)$ marker, whilst $\sum(22: 0,24: 0)$ has also been proposed to be useful as such a marker (e.g. Colombo et al., 1997; Budge et al., 2001). These markers were therefore also analyzed in order to detect any influence of farm feeding routines on wild fish assemblages.

Permutational multivariate analysis of variance (PERMANOVA) was used to test for differences in the overall fatty acid composition among the potential sources of variation (Anderson 2004). We tested whether the main FAs varied between farms and controls using univariate analysis of variance (ANOVA), the factor 'Farm' was considered a random factor with two levels - farm vs. control. Prior to ANOVA, 
heterogeneity of variance was tested with Cochran's $C$-test. As data were percentages, they were arcsine transformed (Underwood, 1997).

\section{RESULTS}

\subsection{Spatial and Temporal Variability in Aggregated Species}

Eighteen fish species, belonging to nine families, were found to settle at the Campello and Guardamar fish farms; Atherinidae, Carangidae, Labridae, Moronidae, Mugilidae, Pomatomidae, Serranidae, Sparidae and Syngnathidae (Fig. 1, Table 1). Juvenile fishes were consistently present around the cages in all months sampled except during April 2006 and March 2007 at Campello, and during December 2007 at Guardamar. Assemblages were dominated by the smallest size-class of each species present. This smallest size class showed variable residence times around cages of between one and four months following each settlement event. Fishes of larger size classes were always lower in abundance and disappeared more rapidly in the months following their appearance.

At both localities, the highest total abundances of juvenile fishes occurred in the summer months, with a maximum of $3783 \pm 1730$ individuals/cage at Campello (July 2006) and 2077 \pm 713 individuals/cage at Guardamar (June 2007). The lowest total abundances occurred from February to April (0 to $41.6 \pm 8.8$ individuals/cage).

In general, there was a change in species abundance with time throughout the sampling period. Atherina spp. peaked in abundance in September 2006 and June 2007 at Guardamar (769.1 \pm 421.3 and 422 \pm 198.3 individuals/cage, respectively, Figure 1). At Campello, however, we observed a much lower Atherina spp. abundance, with a maximum of just 19.5 \pm 19.5 individuals/cage in September 2006 (Figure 1). High abundances of Boops boops occurred in winter (286.3 \pm 30.1 at Guardamar, January 2007, and 216.6 \pm 134.5 at Campello, December 2006, Figure 1), but a sharp decline in abundance occurred in the following months. The sparid Diplodus sargus settled at Guardamar during spring in 2006 and 2007, with a peak of 574.3 \pm 326.6 individuals/cage in May 2007 (Figure 1). At Campello, however, D. sargus was not detected at all during spring 2007. With the exception of April and December 2007, 
mugilids were present continuously around the cages throughout the sampling period, with the highest abundance recorded at Guardamar (363.3 \pm 185.5 individuals/cage, Figure 1) in November 2006. Finally, the sparid Oblada melanura reached the highest abundances for any juvenile fish recorded in the study in the summer months at both farms; Campello: 2355 \pm 1144 (7-20 mm SL) and 1778 \pm 331.7 (20-30 mm SL) individuals/cage, July 2006; Guardamar: 1287.1 \pm 892.2 ( $<7 \mathrm{~mm} \mathrm{SL})$ individuals/cage, June 2007, Figure 1). Species that were present in lower abundances are included in Tables 1 and 2.

\subsection{Diet}

The percentage of empty stomachs was $9.7 \%$ for Atherina spp.; $0 \%$ for Boops boops; $8.3 \%$ for Diplodus sargus; $16.1 \%$ for Liza aurata and $16.3 \%$ for Oblada melanura. The dominant prey item was adult copepods in all of the stomachs analyzed (Fig. 2). The predominance of copepods in the diet was especially obvious for B. boops, L. aurata and $O$. melanura of all sizes ( $>60 \%$ of the diet). After copepods, the diet of these three species also contained a considerable number of copepodites and unidentified crustaceans. Cladocerans were also an important component of the diet of the smallest B. boops. For the smallest sizes of O. melanura, low numbers of nauplius larvae and amphipods were also recorded. In contrast, Atherina spp. and D. sargus stomachs contained other prey items, such as nauplius larvae, copepodites and cladocerans, even though copepods were still the predominant prey item (29-52\% for Atherina spp. and $35-57 \%$ for D. sargus). Amphipods were also a significant component of the diet for both species and, in the case of Atherina spp., this was restricted to the largest individuals. Fish eggs were also an important dietary item for D. sargus and made up 3$7 \%$ of the total items consumed.

\subsection{Prey Selectivity}

Ivlev's index showed that all five studied species actively rejected zoea larvae and cladocerans for consumption (Fig. 3). This pattern was specially marked for $O$. melanura, which selected other prey items such as copepodites $(E=0.18)$ and copepods $(E=0.20)$. Atherina spp. and B. boops both selected copepodites $(E=0.82$ and 1 respectively), and Atherina spp. rejected nauplius larvae $(E=-0.72)$. Juveniles of $D$. 
sargus preferred copepodites $(E=0.30)$ and fish eggs $(E=0.81)$. L. aurata rejected fish eggs and fish larvae, and preferred adult rather than juvenile copepods $(E=0.34$ for copepods).

\subsection{Fatty Acid Composition}

The FA composition of the two types of food pellets used at Campello farm, and the single type used at Guardamar, are indicated in Fernandez-Jover et al. (2007). As is common in the FA composition of commercial aquaculture food pellets, there were high

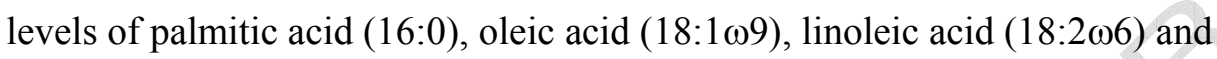
eicosapentaenoic acid (EPA; 20:5 23$)$.

As given by the PERMANOVA test, there were significant differences between the FA profiles of control and farm-associated fish $(\mathrm{F}=6.57, \mathrm{p}<0.01$ for L. aurata, and $\mathrm{F}=6.68$, $\mathrm{p}<0.01$ for $O$. melanura). Significant differences were also detected for some of the individual fatty acids, and fatty acid ratios, for both L. aurata and O. melanura. The

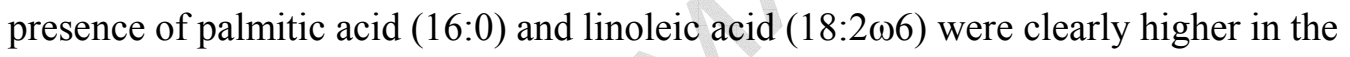
tissue of farm-associated fish than in that of controls (Table 2). There was also

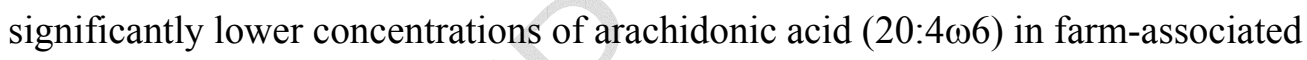
fishes than in controls. For O. melanura, there were significantly higher levels of EPA $(20: 5 \omega 3)$ and total $\omega 7$ acids in farm-associated fish. Significant differences were also found for $\sum(18: 2 \omega 6 ; 18: 3 \omega 3)$ in O. melanura due to increased levels in farm-associated fish (Table 3).

The FA profiles of zooplankton collected at the farms also showed significantly elevated levels of pellet-derived acids compared with zooplankton collected at control locations (Table 2). Indicator $\sum(18: 2 \omega 6 ; 18: 3 \omega 3)$ was 6 times higher in zooplankton collected at farms than at control locations. The ratio w3/w6 was 15 times lower in zooplankton collected from farms than at control locations. This was due to high levels of docosahexaenoic acid (DHA) in control zooplankton communities.

\section{DISCUSSION}


This study has demonstrated that sea-cage fish farms are settlement sites for several fish species in the SW Mediterranean Sea. The almost complete absence of individuals in the open areas between cages suggests that juvenile fishes may associate closely with the floating ring structure of the cages in order to gain protection from predators. Our estimated densities indicate that the most abundant species (i.e. Boops boops, Atherina spp., and Oblada melanura), may reach abundances of $>10000,20000$ and 50000 individuals/farm respectively, depending on the number of cages at the farm studied. The lack of information regarding both the settlement of these species, as well as stock information on adult populations across the Mediterranean mean that it is difficult to relate the influence of aggregations of this magnitude on the total settlement of these species in a particular area.

Our work shows that other species did settle at fish farms, however, they did so in much lower abundances (Table 1) (e.g. Diplodus spp., Seriola spp., Pomatomus saltatrix). Similarly, the two species cultured at Guardamar and Campello farms, Sparus aurata and Dicentrarchus labrax did settle around the cages, however, are not detected as adults except when escape events occur (Dempster et al., 2002; Fernandez-Jover et al., 2008). Factors that cause fishes to select certain settlement sites but not others, are difficult to assess, however, these fishes may use sound or chemical cues from resident fish (Sweatman, 1988; Dempster and Kingsford, 2003; Mann et al., 2007). This does not seem to be the case for $S$. aurata and D. labrax as shown by the low numbers of these species found in the vicinity of the cages. However, many of the species detected as juveniles around cages are found in high abundances and biomasses around SW Mediterranean farms as adults. The presence of adult sparids (Boops boops, Diplodus spp., Oblada melanura), mugilids, and carangids (Trachinotus ovatus, Trachurus mediterraneus) around farms may indicate that some species-specific chemical cues are acting and inducing some species to settle around the cages but, at the moment, no data supports this theory. In addition, the floating cages may influence water currents in the vicinity of farms, leading to the retention of presettlement fish in the same way that coral reefs modify local currents favouring the retention and local settlement of coral reef fish (Kingsford et al., 1991).

Movements between sea-cages and surrounding natural habitats are also important when juvenile fish reach a certain size. It has been previously reported that both Diplodus 
puntazzo and $D$. sargus usually settle on rocky reefs $<2 \mathrm{~m}$ deep, while $D$. vulgaris prefer areas $>2 \mathrm{~m}$ deep. The preference for a particular habitat type decreases as the juveniles grow and dispersal from this habitat occurs when individuals reach 45-55 mm in length (Macpherson, 1998). García-Rubies (1995) showed that juvenile D. sargus, $D$. cervinus, D. puntazzo, D. vulgaris and Sarpa salpa prefer to settle in shallow habitats (< $2 \mathrm{~m}$ deep) consisting mainly of sand, gravel or small blocks. Furthermore, the size-atsettlement recorded by these authors coincided with that recorded for the same species in the present study (i.e. $5-15 \mathrm{~mm}$ ).

Dempster et al. (2002) found adult Boops boops, D. sargus, D. vulgaris, Pomatomus saltatrix, Trachinotus ovatus and Trachurus mediterraneus around the same facilities studied in this work. None of these species of between 60 and $150 \mathrm{~mm}$ SL were found around the cages in this study, which suggest that a connection between different habitats for different developmental stages exists for these species. Natural tagging experiments (e.g. using otolith chemistry; Gillanders and Kingsford, 2000) may be useful to test if individuals which settle at fish farms as juveniles return to the same offshore aquaculture facilities as adults.

For all censused fish species, abundances were highest for the smallest size-classes of fish. Abundances, however, sharply declined in the following months. This may indicate a migration to other habitats when a greater swimming capacity has been attained (Macpherson, 1998), or high mortality rates due to increased predatory pressure (Finn and Kingsford, 1996) as a result of the presence of adult carnivorous fishes around the cages (e.g. Pomatomus saltatrix, Sanchez-Jerez et al., 2008). If the mortality of juvenile fish is high around cages, there exists the potential for negative effects on local fish stocks, since many of the juveniles are species of commercial importance in the Mediterranean. In any case, the predatory behaviour of adult fishes seems to be highly prey size-dependent, and predation on small juveniles is likely to be moderate in the study region. Indeed, the predators Trachurus mediterraneus and Trachinotus ovatus found around cages mainly feed on uneaten food pellets (Fernandez-Jover et al., 2007; 2008). Only a few predator species prey upon wild fish around cages and the size of prey fishes has been shown to be always > $10 \mathrm{~cm}$ SL (Sanchez Jerez et al., 2008; Fernandez-Jover et al., unpublished data). If mortality of juveniles due to predation is moderate around sea-cages, then fish farms may provide shelter as well as appropriate 
settlement habitat for species that otherwise could have potentially drifted offshore to non-suitable settlement areas. This has been previously suggested to generate positive effects on the survivorship of juvenile fishes around oil platforms (Emery et al., 2006).

Very few empty stomachs were recorded for all fish species examined for dietary analysis and prey selectivity, indicating that food was not a limiting resource around fish farms. In addition, despite that all species had consumed high numbers of copepods and copepodites (except L. aurata), Ivlev's index did not show a clear preference for copepods, indicating that the demand for copepods is low relative to their availability. The considerable overlap in diet among all studied species shows that food, and especially copepods, to be a non-limiting factor as all species were able to consume other food items at low rates. Food resources associated with cage nets (mainly amphipods such as Caprella spp. and Jassa spp.) are probably not exploited despite their high abundances on the nets (P. Sanchez-Jerez, pers. obs.). These amphipods, which are larger compared with pelagic food resources, may be oversized for the jaw width of most juvenile fishes. Consequently, our results do not support the suggestion that juvenile fishes settle around sea-cages because of the potential for high food availability associated with the structure of the farm itself (i.e. floating rings, nets, etc.).

The consumption of zooplankton by juvenile fishes aggregated around fish farms may affect the structure of local food webs. Zooplankton collected around fish farms showed

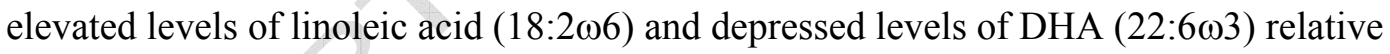
to controls. This pattern is linked to the dramatic differences in $\omega 3 / \omega 6$ ratio and total polyunsaturated acids between control and farm-associated zooplankton. However, this substantial difference may be due to high levels of DHA in zooplankton collected at control sites. Several studies have found similar DHA levels to those we found in zooplankton collected from around farms. Nanton and Castell (1999) found DHA and linoleic acid values of $16 \%$ and $1.5 \%$, respectively, for zooplankton from the Atlantic Ocean. Rossi et al. (2006) detected DHA and linoleic acid levels that ranged between $12-14 \%$ and $2-6 \%$, respectively, for zooplankton from the Mediterranean. These reported values are similar to the DHA levels for farm-associated plankton we detected in this study, however a high proportion of our linoleic acid was of aquaculture food pellet origin. Increments in linoleic acid levels may therefore be a consequence of the consumption of particulate matter arising from uneaten pellets and the faeces of 
cultivated fish by zooplankton around fish farms. In addition, particulate and dissolved organic matter may influence zooplankton fatty acid composition through the microbial and protozoan loop (Mazzocchi and Ribera d'Alcala, 1995; Turner et al., 1988).

This change in the FA composition of zooplankton was reflected in the FA profiles of juvenile fishes associated with the cages. We detected increased levels of linoleic and palmitic acids for both species analyzed. High levels of the terrestrial marker $\sum(18: 2 \omega 6$; $18: 3 \omega 3)$ were also detected for $O$. melanura and this was a result of the high proportion of copepods (with food pellets influence in their composition) in the diet of this species. There was also a significant decrease in arachidonic acid $(22: 4 \omega 6)$ for both species. Marine fishes have specific requirement for dietary arachidonic acid (Castell et al., 1994; Bell and Sargent, 2003) because of its vital function as the main precursor to a wide variety of biologically active compounds, such as the eicosanoids (Tocher and Sargent, 1987). This acid is necessary for the optimal growth, development, and health of juvenile fishes (Bell and Sargent, 2003), and hence may contribute to the larval survivorship of marine teleosts. Further work using controlled experiments in the laboratory is necessary in order to better assess the incorporation rates of this acid in different species. Its residence time in fish tissues must also be quantified if arachidonic acid is to be considered as a potential biomarker for testing the influence of fish farms on the physiology of juvenile fish.

In summary, the results of this work clearly demonstrate that juvenile fishes use seacage fish farms as settlement areas in the SW Mediterranean Sea. The input of FAs of aquaculture origin may be associated with a change in the physiology of juvenile fish species which aggregate there. This also raises the question as to whether offshore aquaculture facilities in the Mediterranean are responsible for attracting juvenile fishes to settle in areas with high abundances of adult predators, or conversely, whether they provide a unique settlement habitat for drifting larvae that may otherwise have perished in the open sea before finding appropriate settlement habitat (Emery, 2006).

\section{Acknowledgments}


We thank the staff of the Cudomar (El Campello) and Martorres (Guardamar) fish farms for their help and to J. Hughes and F. Tuya for language corrections and C. Valle for his help during field sampling. Comments made by J. Dalsgaard helped to improve the manuscript. The study forms part of the ACUFISH project (Dpt. Marine Science and Applied Biology, University of Alicante) and was funded by Spanish Ministry of Science grant MYCT-REN2003-00794.

\section{References}

Anderson, M.J., 2004. PERMANOVA_2factor: a FORTRAN computer program for permutational multivariate analysis of variance (for any two-factor ANOVA design) using permutation tests. Department of Statistics, University of Auckland, New Zealand.

Bell, J.G., Sargent, J.R., 2003. Arachidonic acid in aquaculture feeds: current status and future opportunities. Aquaculture 218, 491-499.

Beets, J., 1989. Experimental evaluation of fish recruitment to combinations of fish aggregating devices and benthic artificial reefs. Bulletin of Marine Science 44 (2), $973-$ 983.

Budge, S.M., Parrish, C.C., Mckenzie, C.H., 2001. Fatty acid composition of phytoplankton, settling particulate matter and sediments at a sheltered bivalve aquaculture site. Marine Chemistry 76 (4), 285-303.

Castell, J.D., Bell, J.G., Tocher, D.R., Sargent, J.R., 1994. Effects of purified diets containing different combinations of arachidonic and docosahexaenoic acid on survival, growth and fatty acid composition of juvenile turbot (Scophthalmus maximus).

Aquaculture 128, 315-333.

Colombo, J.C., Silverberg, N., Gearing, J.N. 1997. Lipid biogeochemistry in the Laurentian Trough - II. Changes in composition of fatty acids, sterols and aliphatic hydrocarbons during early diagenesis. Organic Geochemistry 26:257-274. 
Dempster, T., Sanchez-Jerez, P., Bayle-Sempere, J.T., Giménez-Casalduero, F., Valle, C., 2002. Attraction of wild fish to sea-cage fish farms in the south-western Mediterranean Sea: spatial and short-term temporal variability. Marine Ecology Progress Series 242, 237-252.

Dempster, T., Kingsford, M.J., 2003. Homing of pelagic fish to fish aggregation devices (FADs): the role of sensory cues. Marine Ecology Progress Series 258, 213-222.

Emery, B.M., Washburn, L., Love, M.S., Nishimoto, M.M., Ohlmann, J.C., 2006. Do oil platforms off California reduce recruitment of bocaccio (Sebastes paucispinis) to natural habitat? An analysis based on trajectories derived from high-frequency radar. Fisheries Bulletin 104, 391-400.

FAO, 2007. Cage aquaculture. Regional reviews and global overview. FAO Fisheries Technical Paper No. 498. Rome, FAO. 241 pp.

Fernandez-Jover, D., Lopez-Jimenez, J.A., Sanchez-Jerez, P., Bayle-Sempere, J.T., Gimenez-Casalduero, F., Martinez-Lopez, F.J., Dempster, T. 2007. Changes in body condition and fatty acid composition of wild Mediterranean horse mackerel (Trachurus mediterraneus, Steindachner, 1868) associated with sea cage fish farms. Marine Environmental Research 63, 1-18.

Fernandez-Jover, D., Sanchez-Jerez, P., Bayle-Sempere, J.T., Valle, C., Dempster, T. 2008. Seasonal patterns and diets of wild fish assemblages associated to mediterranean Coastal fish farms. ICES Journal of Marine Science 65, 1153-1160.

Finn, M.D., Kingsford, M.J. 1996. Two-phase recruitment of Apogonids (Pisces) on the Great Barrier Reef. Marine and Freshwater Research 47 (2), 423-432.

Folch, J., Lees, M., Stanley, G.A. 1957. A simple method for the isolation and purification of total lipids from animal tissues. Journal of Biological Chemistry 226:497-509 
Freon, P., Dagorn, L. 2000. Review of fish associative behaviour: toward a generalisation of the meeting point hypothesis. Reviews in Fish Biology and Fisheries $10,183-207$.

García-Rubies, A., Macpherson, E., 1995. Substrate use and temporal pattern of recruitment in juvenile fishes of the Mediterranean littoral. Marine Biology 124, 35-42.

Gillanders, B.M., Kingsford, M.J., 2000. Elemental fingerprints of otoliths of fish may distinguish estuarine 'nursery' habitats. Marine Ecology Progress Series 201, 273-286.

Gooding, R.M., Magnuson, J.J., 1967. Ecological significance of a drifting object to pelagic fishes. Pacific Science 21, 486-497.

Govoni, J.J., Pietrafesa, L.J., 1994. Eulerian views of layered water currents, vertical distribution of some larval fishes, and inferred advective transport over the continental shelf of North Carolina, USA, in winter. Fisheries Oceanography 3, 120-132.

Ivlev, V.S. 1961. Experimental Ecology of the Feeding of Fishes. Yale University Press, New Haven. CI.

Johnson, D.H., 1980. The comparison of usage and availability measurements for evaluating resource preference. Ecology 61, 65-71.

Kingsford, M.J., Wolanski, E., Choat, J.H., 1991. Influence of tidally induced fronts and Langmuir circulations on distribution and movement of presettlement fishes around a coral reef. Marine Biology 109, 167-180.

Love, M., Hyland, J., Ebeling, A, Herrlinger, T., Brooks, A., Imamura, E., 1994. A pilot study of the distribution and abundances of rockfishes in relation to natural environmental-factors and an offshore oil and gas-production platform off the coast of southern California. Bulletin Marine Science 55, 1062-1085.

Macpherson, E., 1998. Ontogenic shifts in habitat use and aggregation in juvenile sparid fishes.Journal of Experimental Marine Biology and Ecology 220, 127-150. 
Mann, D.A., Casper, B.M., Boyle, K.S., Tricas, T.C., 2007. On the attraction of larval fishes to reef sounds. Marine Ecology Progress Series 338, 307-310.

Mazzocchi, M.G., Ribera d'Alcala, M., 1995. Recurrent patterns in zooplankton structure and succession in a variable coastal environment. ICES Journal of Marine Science 52, 679-691.

Nanton, D.A., Castell, J.D., 1999. The effects of temperature and dietary fatty acids on the fatty acid composition of harpacticoid copepods, for use as a live food for marine fish larvae. Aquaculture 175, 167-181

Powers, M.J., Peterson, C.H., Summerson H.C., Powers, S.P., 2007. Macroalgal growth on bivalve aquaculture netting enhances nursery habitat for mobile invertebrates and juvenile fishes. Marine Ecology Progress Series 339, 109-122.

Rilov, G., Benayahu, Y. 2000. Fish assemblage on natural versus vertical artificial reefs: the rehabilitation perspective. Marine Biology 136 (5), 931-942.

Rossi, S,, Sabatés, A., Latasa, M., Reyes, E. 2006. Lipid biomarkers and trophic linkages between phytoplankton and anchovy (Engraulius encrasicolus) larvae in the NW Mediterranean. Journal of Plankton Research 28, 551-562.

Sanchez-Jerez, P., Fernandez-Jover, D., Bayle-Sempere, J., Valle, C., Dempster, T., Tuya, F., Juanes, F., 2008. Interactions between bluefish Pomatomus saltatrix (L.) and coastal sea-cage farms in the Mediterranean Sea. Aquaculture 282, 61-67

Sherman, K., Smith, W., Morse, W., Berman, M., Green, J., Ejsymont, L., 1984. Spawning strategies of fishes in relation to circulation, phytoplankton production, and pulses in zooplankton off the northeastern United States. Marine Ecology Progress Series 18, 1-19. 
Stoffel, W., Chu, F., Edward, H., 1959. Analysis of Long-chain fatty acids by GasLiquid chromatography. Micromethod for preparation of methyl esters. Analytical Chemistry 31, 307-308.

Sweatman, H., 1988. Field evidence that settling coral reef fish larvae detect resident fishes using dissolved chemical cues. Journal of Experimental Marine Biology and Ecology 124 (3), 163-174

Tocher, D.R., Sargent, J.R., 1987. The effect of calcium ionophore A23187 on the metabolism of arachidonic and eicosapentaenoic acids in neutrophils from a marine fish rich in n-3 (polyunsaturated fatty acid). Comparative Biochemistry and Physiology BBiochemistry and Molecular Biology 87, 733-739.

Turner, J.T., Tester, P.A., Ferguson, R.L. 1988. The marine cladoceran Penilia avirostris and the microbial loop of pelagic food webs. Limnology and Oceanography $33,245-255$.

Underwood, A.J., 1997. Experiments in ecology. Their logical design and interpretation. Cambridge University Press, UK 


\section{Tables}

Table 1. Abundances (individuals/cage \pm standard error) of fish species counted around the two studied fish farms, A) Guardamar and B) Campello, over a 22 month period. Species are (left to right): Dicentrarchus labrax, Diplodus cervinus, Diplodus puntazzo, Diplodus vulgaris, Unidentified sparids, Pomatomus saltatrix, Sarpa salpa, Seriola spp., Serranus scriba, Sparus aurata, unidentified syngnathids, Symphodus roisalli, Trachinotus ovatus and Trachurus mediterraneus. Densities of the most abundant species are shown in Figure 1.

\section{A) GUARDAMAR}

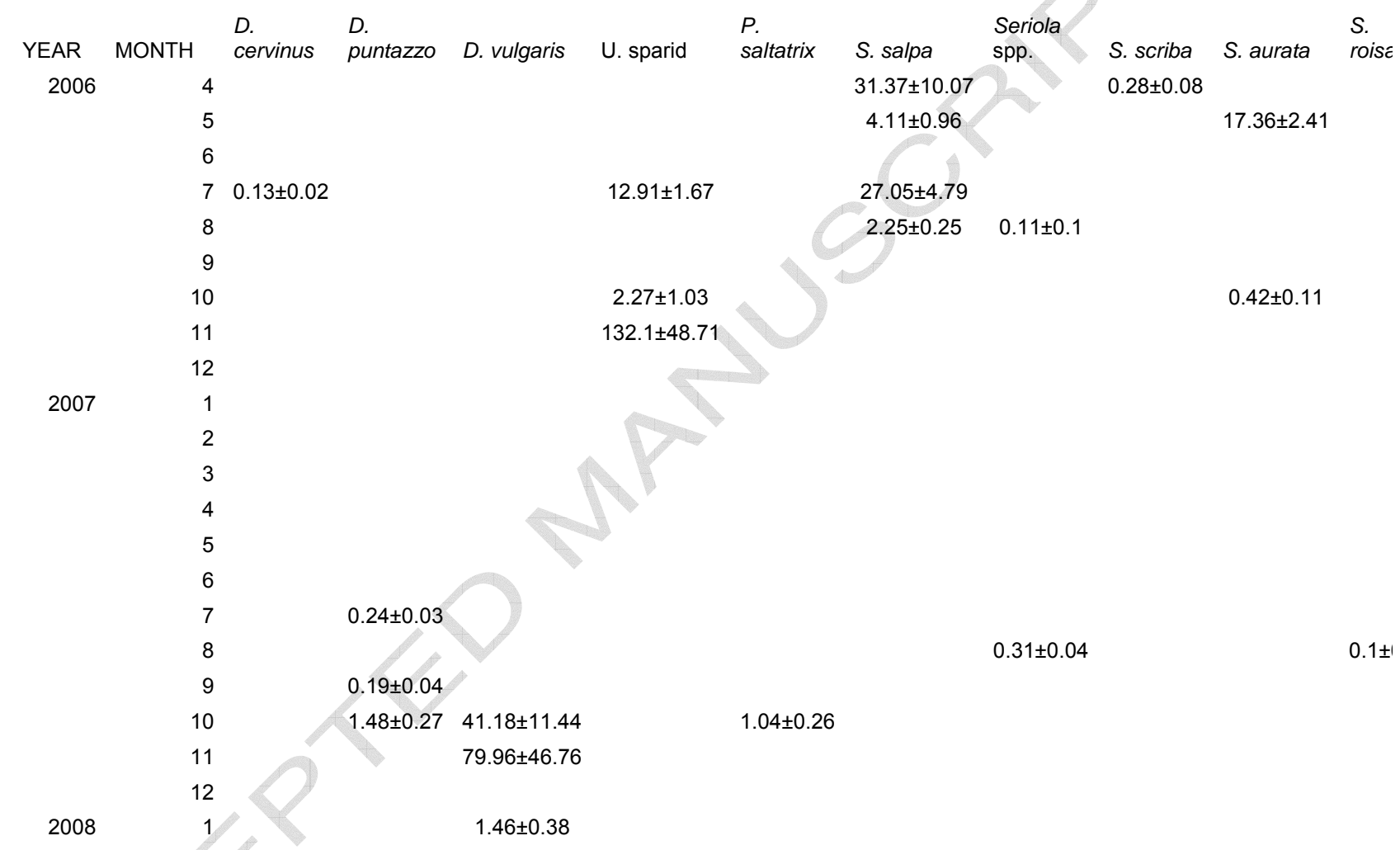

\section{B) CAMPELLO}

\begin{tabular}{|c|c|c|c|c|c|c|c|c|c|c|c|}
\hline \multicolumn{2}{|c|}{ YEAR MONTH } & D. labrax & D. cervinus & $\begin{array}{l}\text { D. } \\
\text { puntazzo }\end{array}$ & D. vulgaris & U. sparid & P. saltatrix & $\begin{array}{l}\text { S. } \\
\text { salpa }\end{array}$ & Seriola spp. & $\begin{array}{l}\text { U. } \\
\text { syngnathid }\end{array}$ & T. ovatu \\
\hline \multirow[t]{9}{*}{2006} & 4 & & & & & & & & & & \\
\hline & 5 & & & & & & & & & & \\
\hline & 6 & & & & $0.82 \pm 0.14$ & & & & & & \\
\hline & 7 & $0.14 \pm 0.02$ & $0.57 \pm 0.11$ & & & & & & $0.14 \pm 0.02$ & & $4.13 \pm c$ \\
\hline & 8 & $0.26 \pm 0.03$ & $0.3 \pm 0.06$ & & & & & & & & $214.45 \pm$ \\
\hline & 9 & & & & & & & & & & \\
\hline & 10 & & & & & $10.58 \pm 3.65$ & & & & & \\
\hline & 11 & & & & & $45.75 \pm 12.11$ & & & & & \\
\hline & 12 & & & $0.74 \pm 0.19$ & & & & & & & \\
\hline \multirow[t]{2}{*}{2007} & 1 & & & $0.23 \pm 0.06$ & & & & & & & \\
\hline & 2 & & & & & & & & & & \\
\hline
\end{tabular}




$\begin{array}{rr} & 3 \\ & 4 \\ & 5 \\ & 6 \\ & 7 \\ & 8 \\ & 9 \\ & 9 \\ & 10 \\ & 11 \\ & 12 \\ 2008 & 1\end{array}$

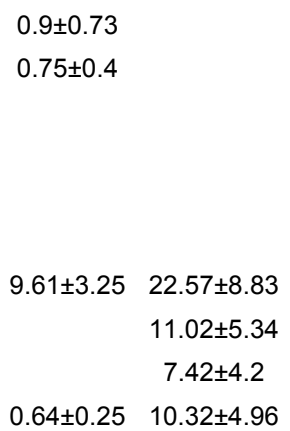

Table 2. Fatty acid composition of juvenile Liza aurata, O. melanura and zooplankton collected from farm and control locations. Data is expressed as percentages \pm standard deviations.

\begin{tabular}{lllllll} 
& \multicolumn{2}{c}{ Zooplankton } & \multicolumn{2}{c}{ Liza aurata } & \multicolumn{2}{c}{ Oblada melanura } \\
& \multicolumn{1}{c}{ Farm } & \multicolumn{1}{c}{ Control } & \multicolumn{1}{c}{ Farm } & \multicolumn{1}{c}{ Control } & \multicolumn{1}{c}{ Farm } & Control \\
C16:0 & $22.27 \pm 2.52$ & $16.16 \pm 1.26$ & $21.23 \pm 1.55$ & $19.75 \pm 0.85$ & $22.71 \pm 2.08$ & $20.89 \pm 1.05$ \\
C16:1 n-7 & $3.39 \pm 1.47$ & $1.08 \pm 0.19$ & $2.94 \pm 1.4$ & $2.73 \pm 0.52$ & $1.8 \pm 0.36$ & $2.15 \pm 0.78$ \\
C18:0 & $9.16 \pm 3.53$ & $4.85 \pm 0.83$ & $8.15 \pm 1.71$ & $9.12 \pm 1.26$ & $9.99 \pm 1.73$ & $11.53 \pm 0.94$ \\
C18:1 n-9 & $11.54 \pm 5.9$ & $5.05 \pm 0.57$ & $8.45 \pm 2.31$ & $7.7 \pm 1.25$ & $6.84 \pm 1.44$ & $7.02 \pm 0.73$ \\
C18:2 n-6 & $9.82 \pm 5.73$ & $1.5 \pm 0.2$ & $3.98 \pm 3.11$ & $2.08 \pm 0.59$ & $2.12 \pm 0.49$ & $1.51 \pm 0.16$ \\
C20:4 n-6 & $0.42 \pm 0.41$ & $0.22 \pm 0.17$ & $0.99 \pm 0.25$ & $1.98 \pm 0.22$ & $1.32 \pm 0.15$ & $3.5 \pm 0.69$ \\
C20:5 n-3 & $8.36 \pm 3.18$ & $14.53 \pm 0.92$ & $7.49 \pm 1.19$ & $9.26 \pm 1.1$ & $8.57 \pm 1.36$ & $8.20 \pm 0.84$ \\
C22:6 n-3 & $12.29 \pm 3.06$ & $45.86 \pm 2.55$ & $31.23 \pm 3.94$ & $29.8 \pm 3.97$ & $32.68 \pm 5.92$ & $31.01 \pm 1.95$ \\
n-3 & $23.82 \pm 7.02$ & $62.34 \pm 3.51$ & $42.21 \pm 3.58$ & $43.84 \pm 4.23$ & $42.81 \pm 7.68$ & $41.17 \pm 1.8$ \\
n-6 & $14.3 \pm 7.68$ & $1.99 \pm 0.32$ & $6.59 \pm 3.24$ & $6.97 \pm 1.81$ & $5.79 \pm 1.88$ & $7.17 \pm 1.19$ \\
n-7 & $5.42 \pm 2.58$ & $1.82 \pm 0.24$ & $5.16 \pm 1.65$ & $5.3 \pm 0.71$ & $3.65 \pm 0.49$ & $4.7 \pm 0.9$ \\
n-9 & $14.51 \pm 6.02$ & $7.8 \pm 0.72$ & $10.05 \pm 2.41$ & $8.73 \pm 1.3$ & $7.87 \pm 1.64$ & $8.13 \pm 0.8$ \\
Saturated & $41.96 \pm 8.47$ & $26.05 \pm 2.89$ & $36 \pm 3.44$ & $35.13 \pm 1.73$ & $39.89 \pm 4.63$ & $38.83 \pm 2.08$ \\
Monounsaturated & $19.92 \pm 8.32$ & $9.62 \pm 0.78$ & $15.2 \pm 2.88$ & $14.06 \pm 1.78$ & $11.52 \pm 2.01$ & $12.83 \pm 0.28$ \\
polyunsaturated & $38.12 \pm 4.77$ & $64.34 \pm 3.32$ & $48.8 \pm 2.26$ & $50.81 \pm 2.81$ & $48.6 \pm 6.13$ & $48.34 \pm 2.03$ \\
n-3/n-6 & $2.44 \pm 2.04$ & $32.32 \pm 7.67$ & $7.97 \pm 3.82$ & $6.89 \pm 2.56$ & $8.23 \pm 3.21$ & $5.88 \pm 0.97$ \\
$\Sigma(18: 2 w 6 ;$ 18:3w3) & $10.83 \pm 6.64$ & $2.16 \pm 0.29$ & $5.04 \pm 3.59$ & $3.55 \pm 0.86$ & $2.71 \pm 0.66$ & $2.08 \pm 0.3$
\end{tabular}


Table 3. ANOVA results for comparison of the main fatty acid composition of A)

Oblada melanura and B) Liza aurata collected from fish farms and control locations. * $\mathrm{p}<0.05, * * \mathrm{p}<0.01, * * * \mathrm{p}<0.001$.

\section{Value of ANOVA F-statistic}

df Linoleic acid DHA

$\sum(18: 2 \omega 6 ; 18: 3 \omega 3)$ Palmitic acid $\omega 3 / \omega 6$ Arachidonic acid EPA

A) Oblada melanura

Farm/Control

$112.09^{* *}$

0.49

$9.14^{* *}$

$4.84^{*}$

$3.18108 .8^{\star * *}$

$24.9^{* * *}$

Total

15

B) Liza aurata

Farm/Control

Residual

$14.69^{*}$

22

Total

23

$8.38^{* *}$

$0.4425 .08^{* * *}$

0.52 
Figure 1. Species abundances (individuals/cage \pm standard error) of juvenile fish of multiple sizes classes (mm SL) around Guardamar and Campello fish farms over the sampling period (April 2006-January 2008).
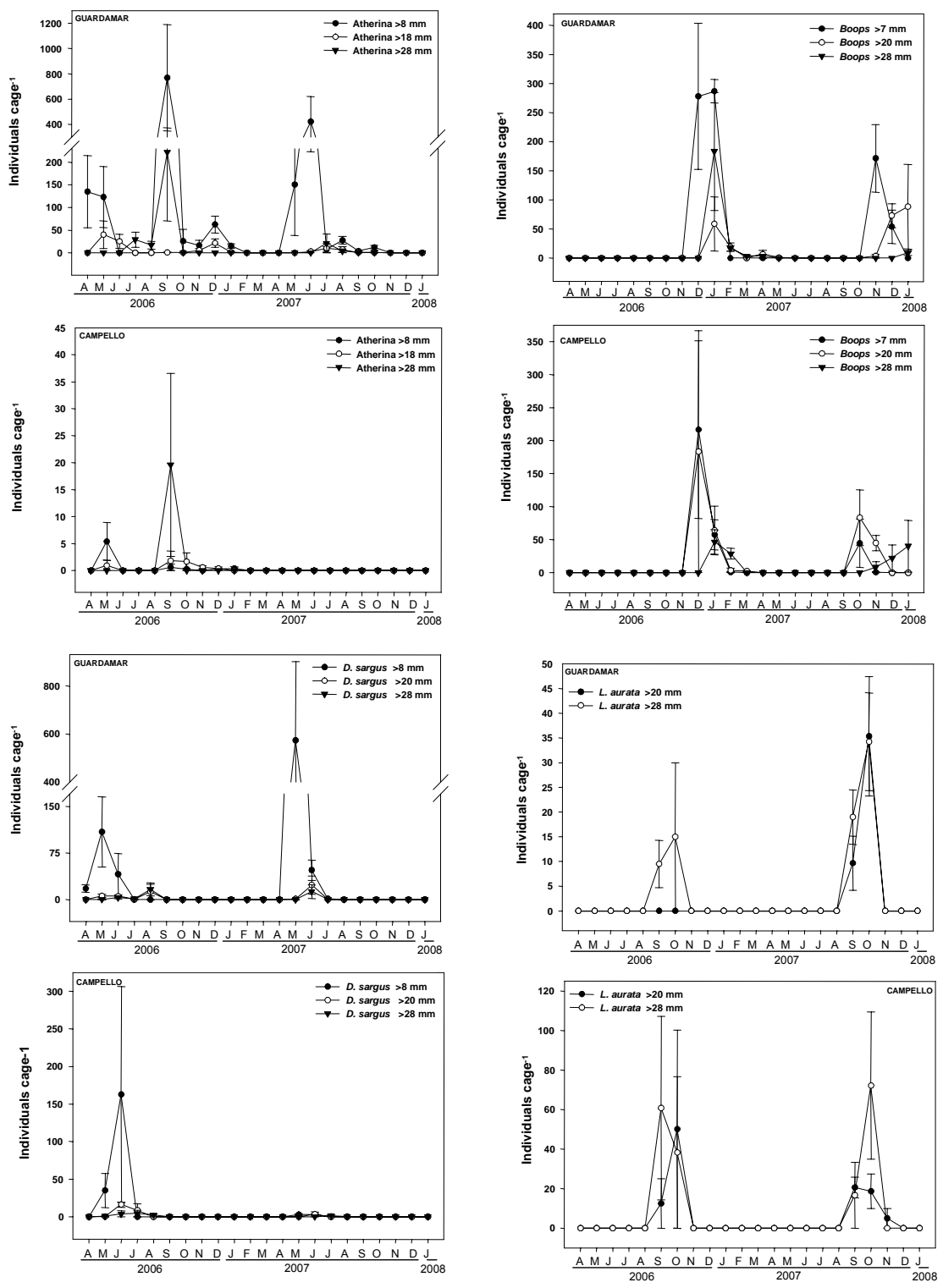

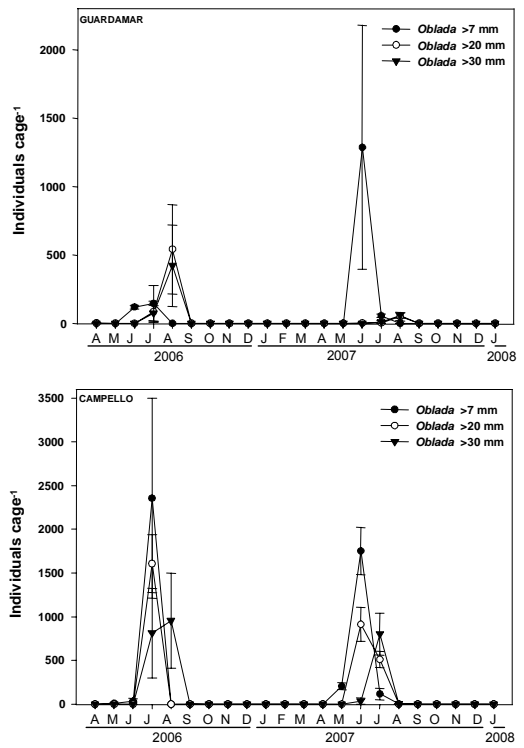
Figure 2. Diet composition (percent) of the main species aggregated around fish farms as a function of body length (mm SL).
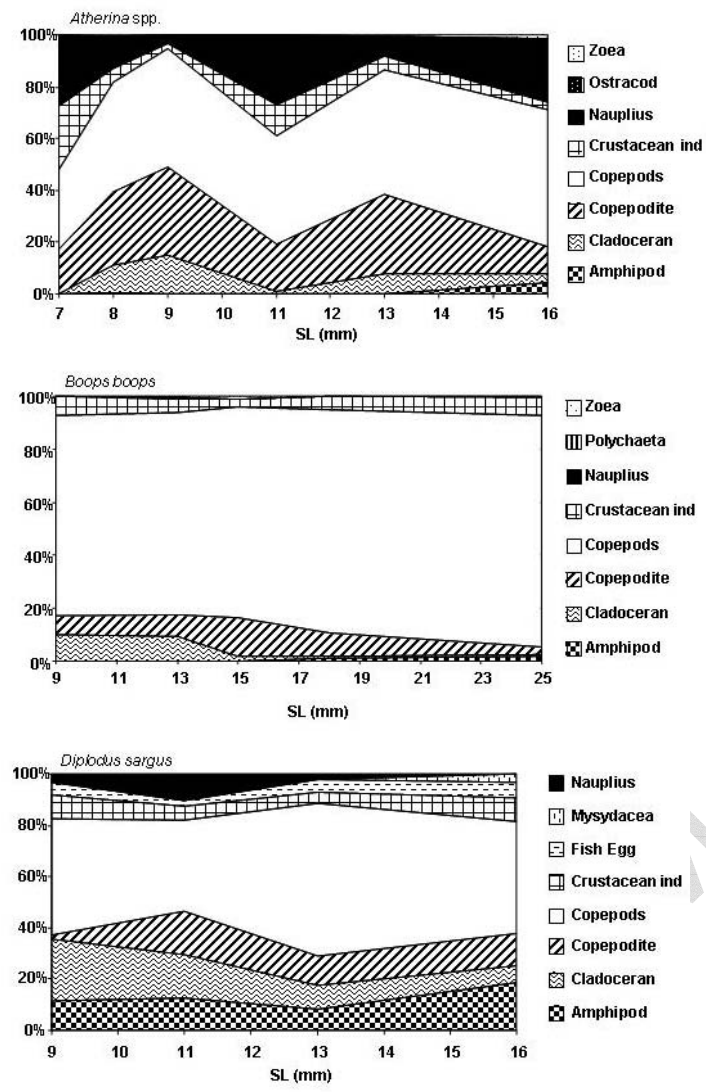

Nauplius

(5) Mysydacea

G Fish Egg

$\square$ Crustacean ind

$\square$ Copepods

$\square$ Copepodite

曾 Cladoceran

Amphipod

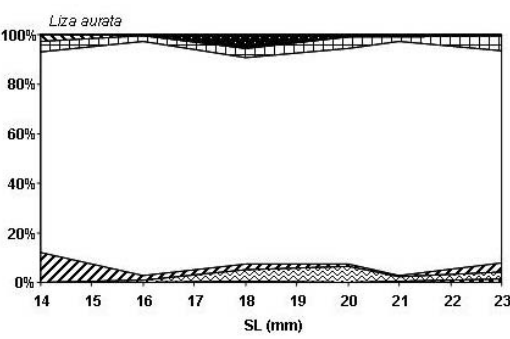

Oostracod

ENauplius

SHexapoda

$\boxplus$ Crustacean ind

$\square$ Copepods

7 Copepodite

图Cladoceran

QAmphipod

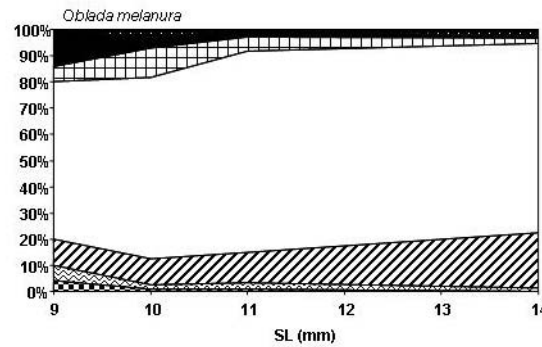

Ostracod

Nauplius

Fish Eggs

Ð) Crustacean ind

$\square$ Copep tot

Copepodite

图 Cladoceran

8 Amphipod 
Figure 3. Ivlev's index showing the prey preferences of Atherina spp., Boops boops,

Diplodus sargus, Liza aurata and Oblada melanura. Negative values indicate rejection and positive values indicate preference for that prey item.

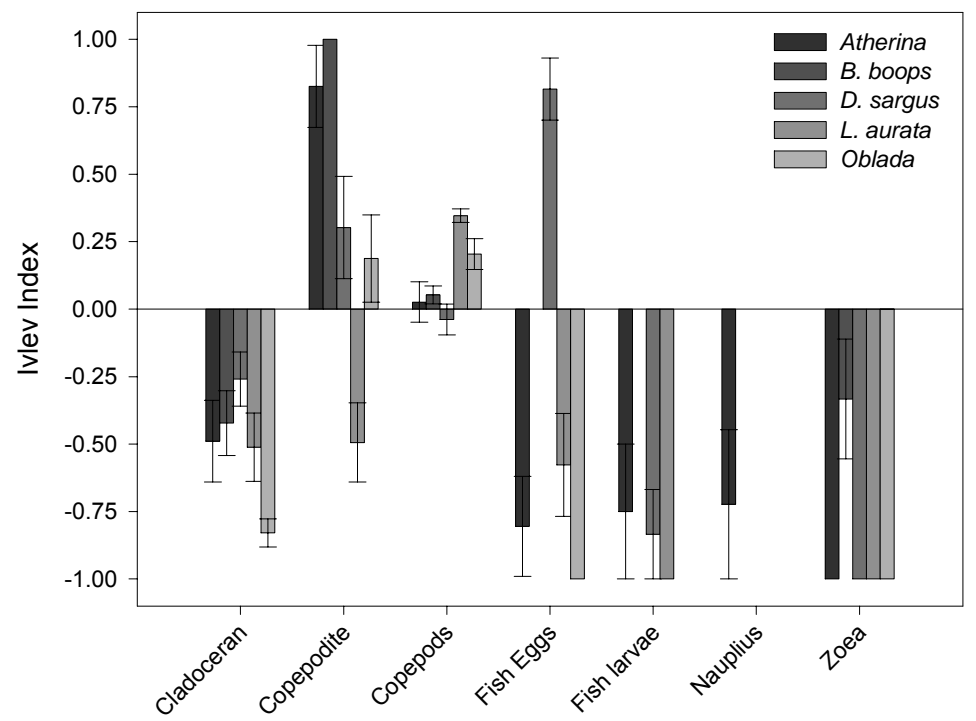

